Indonesian Journal of EFL and Linguistics

Vol. 3 No. 2, 2018

eISSN: 2503-4197, pISSN: 2527-5070

www. indonesian-efl-journal.org

\title{
A Study of Academic Oral Presentation Anxiety and Strategy Employment of EFL Graduate Students
}

\author{
Shiauping Tian \\ National Taiwan University of Science and Technology \\ e-mail: sptian@mail.ntust.edu.tw \\ Masykur Mahmud \\ National Taiwan University of Science and Technology \\ e-mail:mmahmud1808@yahoo.com
}

\begin{abstract}
:
This study investigates the factors contributing to academic oral presentation anxiety, explore the differences between English majors and non-English majors in their strategy employment for academic oral presentations, examine the relationship between academic oral presentation anxiety and strategy employment, and compare the differences in oral communication strategy employment between high-anxiety and low-anxiety students. A total of sixty-one participants participated in this study by answering two questionnaires: Personal Report of Public Speaking Anxiety (PRPSA) (McCroskey, 1970) and Oral Communication Strategy Inventory (OCSI) (Nakatani, 2006), and a follow-up interview was conducted focusing on high and low-anxiety students as defined by the result on PRPSA. Results showed that the three major sources of anxiety related to content of presentation, oral proficiency, and delivery skill. Moreover, a significant difference was found in the use of Social Affective strategies between English majors and non-English majors. Besides, negative significant correlations were found in the use of Message Abandonment strategies and Attempt to Think in English strategies. Furthermore, a statistically significant difference was found in the use of Message Abandonment strategies between high-anxiety and low anxiety-students. Pedagogical implications for reducing anxiety in academic oral communication were discussed.
\end{abstract}

Keywords: Academic oral presentation, anxiety, oral communication strategy

Indonesian Journal of EFL and Linguistics, 3(2), 2018 


\section{INTRODUCTION}

For the past few decades, oral presentations have been increasingly used for assessment purposes in many language learning classrooms. Students are required to have not only good English command, but also good presentation skills in order to succeed in school. Such is the case in graduate students' academic life, in which oral presentations are necessary not only as a course requirement, but also for conference presentations, and proposal and thesis defense. However, anxiety has long been an issue within the context of oral presentation where solution to overcoming such issues has not been explored comprehensively, particularly in terms of strategy use to cope with anxiety.

Good oral communication is essential in oral presentation. Being able to communicate clearly and effectively contributes significantly to the success of presentation. Communication itself does not only rely upon speaking skills, listening is also involved in which understanding is an important aspect to make the message understood by the receiver or audience. The speaker is likely to hinder the messages upon receivers when pronunciation, intonation, or even nonverbal signs are not used appropriately. Moreover, successful communication not only requires competence in language structures, lexicon, and phonology, but also implies a knowledge of the socio-linguistic norms and conventions of community where the language is spoken (Halliday, 1978, as cited in Busa, 2010). As a result, relevant strategies to help learners cope with anxiety should be learned through practices and training regarding strategy employment.

Anxiety has been identified as one of the main factors affecting oral presentation performance, especially for foreign and second language learners. Howirtz, Horwitz, and Cope (1986) mentioned that speaking was the skill most affected by foreign language anxiety. Other studies also identified speaking anxiety as an important factor affecting students' performance in oral presentations (Mak, 2011; Samimy \& Tabuse, 1992; Yusoff, 2008; 2010). Since making oral presentations is such an indispensable part of graduate students' academic life, the current study would make a more in-depth investigation of EFL graduate students' public speaking anxiety to obtain relevant results for future references on academic presentation training and anxiety coping strategies.

\section{LITERATURE REVIEW}

\subsection{Anxiety and Oral Performance}

Similar to studies on the effect of anxiety on general language learning performance, a negative relationship has been found between anxiety and oral performance. Anxiety is believed to negatively affect the quality of communication or willingness to communicate (Young, 1991). Hewitt and Stephenson (2012) explored the effect of anxiety on students' oral exam performance and students' opinion about the experience of taking an oral exam in a foreign language. In their study, a statistically significant modest negative correlation was found between language anxiety and oral accomplishment in university students from an elective English course. 
Neff (2007), investigating second-year university students in Japan, reported a similar finding that higher anxiety led to less effective oral presentation delivery. In addition to a significant negative relationship between second language speaking anxiety and oral performance, Woodrow (2006) reported that advanced English students regarded giving an oral presentation and performing in English in front of classmates as the major causes of anxiety. Samimy and Tabuse (1992) also asserted that speaking anxiety was one of the most important factors in determining the oral performance of American university students of Japanese. Mak (2011) supported such view by identifying speaking in class as the most frequently cited concern for anxious second language learners. Yusoff's (2008; 2010) study on Malyasian engineering students also suggested that although the students are technically sound, they had difficulty with communication skills, especially in oral and presentation skills.

\subsection{Sources of Oral Anxiety}

Although different studies reveal different factors associated with anxiety, some common issues have been identified frequently such as language barrier, proficiency related issue, and class presentation (Amiryousefi \& Tavakoli, 2011; Khattak, et al., 2011; Radzuan and Kaur, 2011; Vitasari, et al, 2010). Hashemi (2011) found that a strict and formal classroom environment is believed to be a significant cause of students' language anxiety, indicating that a formal classroom which demands more correct and clearer use of the target language often leads to anxiety.

Horwitz, Horwitz, and Cope (1986) asserted that certain beliefs about language learning may create anxiety and prevent the development of second language fluency and performance. Other factors such as shyness, interactional domains, and inexperience with western educational practices were found to lead to reticence and anxiety in Japanese learners (Cutrone, 2003, as cited in Neff, 2007).

In terms of oral presentation, Radzuan and Kaur (2011) found that demanding and provocative evaluation panels and limited knowledge and barriers in students' English language proficiency became sources of anxiety associated with delivering presentation. This study showed that giving comments during presentation would also arouse anxiety level.

Chen (2009) conducted a study to investigate graduate students' anxiety level and identify sources of anxiety for academic oral presentation. The study revealed that the students were moderately anxious, and two factors contributing to anxiety were found - social and psychological factors. Social factors included peer responses and audience familiarity; whereas psychological factors included self-perceived oral proficiency, self-perceived accuracy of pronunciation, and self-perceived personality.

Mak (2011) reported five factors as the most influential contributing to speaking-inclass anxiety; those were speech anxiety and fear of negative evaluation, uncomfortableness when speaking with native speakers, negative attitudes towards the English classroom, negative self-evaluation, and fear of failing the class/consequences of personal failure. The study also identified two additional 
factors - insufficient wait-time and inability to use L1 - that influence speaking-inclass anxiety.

Using the Turkish version of Horwitz's (1986) Foreign Language Learning Anxiety Scale (FLLAS) as well as open-ended questions to further elicit self-reports of foreign language anxiety, Kunt and Tum (2010) investigated student teachers' foreign language anxiety in a teacher education program. The findings indicated that nervous and uncomfortable feelings due to attitudes of native speakers in the classroom were found to contribute to anxiety. Native speakers tended to monopolize class time; therefore, students had few opportunities to use the target language. Moreover, according to students' responses there was a lack of courses aimed at developing skills in the teacher education program.

In addition to finding a significant negative relationship between second language speaking anxiety and oral performance, Woodrow (2006) also reported that advanced English students regarded giving an oral presentation and performing in English in front of classmates as major stressors.

A study with postgraduate students in Pakistan (Ahmed, Pathan, \& Khan, 2017), using 18 items on foreign language speaking anxiety from Foreign Language Classroom Anxiety Scale (FLCAS), revealed that students attributed their speaking anxiety to inter-language meaning system, fear of making grammatical errors, and disappointment as they tried to speak fluently in class.

In a more recent study by Amiri and Puteh (2018), international doctoral students from public universities in Malaysia reported some factors significantly contributing to academic oral communication anxiety, categorized into language issues, deficiency of knowledge of research, negative perceptions towards the oral examiner or audience (such as examiner's negative personality traits and language deficiency), and others (including vague comments during presentation and confusion over some conventions in oral defense sessions).

Overall, factors contributing to anxiety in speaking as identified in previous studies are generally related to language skills, audience response, and psychological issues.

\subsection{Training to Reduce Speaking Anxiety and Improve Performance}

To address the negative impact of speaking anxiety on students' performance, researchers have proposed and tested different ways to help students conquer anxiety and improve public speaking skills. So far positive results have been reported.

King (2002) asserted that relevant and organized trainings can help students greatly. He commented that "the introduction of oral presentations to EFL classrooms provides a rewarding and stimulating experience both for teachers in developing facilitating skills and for students in training themselves to have confidence in public.”(p.413) Moreover, Busá (2010) found that multimedia resources such as pictures and illustrations, digital slides, audio files for pronunciation exercises seemed to be highly effective in raising students' awareness of facts about English communication and its workings. Students showed a definite improvement in oral presentation. In addition, Colbeck (2011) found that a basic-level speech course 
combining three approaches, systematic desensitization, cognitive restructuring, and skill-building, was able to significantly reduce college students' anxiety in oral communication. Mazdayasna (2012) showed that teaching students how to do oral presentation using a story provided by the instructor effectively improved EFL learners' oral performance; it also indicated that students were able to adjust their performance if assessment of oral presentations were done according to established criteria.

Adopting a group tutoring approach, Knight, Johnson, and Stewart (2016) investigated the effectiveness of interventional strategies in helping students in a public speaking course. Results of their study indicated that after the group tutoring, students improved significantly in their ability to use evidence to support main ideas and to effectively structure their presentations, as evidenced in their recorded speeches. Students' self-ratings of communication apprehension also showed increased comfort level in working in small meetings.

Moreover, a study conducted in Taiwan by Hsu (2012) employing Personal Report of Public Speaking Anxiety (PRPSA) by McCroskey (1970) revealed that a yearlong public speaking course had indeed helped diminish some if not all of the students' public speaking anxiety, and a significant relationship was found between public speaking anxiety and gender.

From previous literature, it is clear that anxiety derived from various sources plays a significant role in students' speaking performance, especially for EFL and ESL students. Nevertheless, not much research has looked into academic oral presentation anxiety, which is an increasing important challenge for graduate students and can differ in nature from general oral presentations or other classroom speaking activities. Therefore, the present study aims to better understand the anxiety and strategy use of graduate students in making academic presentation by converging both quantitative and qualitative data. In this study, the Personal Report of Public Speaking Anxiety (PRPSA) and questionnaire on Oral Communication Strategy are used to measure the relationship between oral presentation anxiety and strategy use. At the same time, factors contributing to oral presentation anxiety are explored using semi-structured interview with the high and low anxious graduate students in Taiwan. The following research questions are addressed:

1. What are the most influential factors contributing to oral presentation anxiety in graduate students?

2. Is there any relationship between academic oral presentation anxiety and strategy employment?

3. Is there any significant difference in strategy employment between English majors and non-English majors?

4. Is there any significant difference in strategy employment between highanxious and low-anxious students? 


\section{RESEARCH METHODOLOGY}

\subsection{Participants}

Sixty-one graduate students (15 Taiwanese and 46 international students) enrolled in universities in North Taiwan participated in the study. 24 of them were English majors and 37 non-English majors. Background information of these graduate students is provided in Tables 1-3.

Table 1 Participants' Nationality Distribution

\begin{tabular}{lll}
\hline Nationality & Number $(N=61)$ & Percentage $(\%)$ \\
\hline Indonesia & 40 & 65.6 \\
Taiwan & 15 & 24.6 \\
Russia & 3 & 4.9 \\
Iraq & 1 & 1.6 \\
Thailand & 1 & 1.6 \\
Vietnam & 1 & 1.6 \\
\hline
\end{tabular}

Table 2 Gender Distribution of Participants

\begin{tabular}{lll}
\hline Gender & Number $(N=61)$ & Percentage $(\%)$ \\
\hline Male & 24 & 39.3 \\
Female & 37 & 60.7 \\
\hline
\end{tabular}

Table 3 Academic Majors of Participants

\begin{tabular}{lll}
\hline Major & Number $(\mathrm{N}=61)$ & Percentage \\
\hline Arts and Humanities & 27 & 34.4 \\
Science & 4 & 6.6 \\
Business & 3 & 4.9 \\
Management & 8 & 13.1 \\
Engineering & 15 & 24.6 \\
Design & 4 & 6.6 \\
\hline
\end{tabular}

\subsection{Instruments}

In addition to a background information questionnaire, participants' academic oral presentation anxiety was measured by Personal Report of Public Speaking Anxiety (PRPSA) developed by McCroskey (1970), while Oral Communication Strategy employment was revealed through the Oral Communication Strategy Inventory designed by Nakatani (2006).

\subsubsection{Personal Report of Public Speaking (PRPSA)}

The Personal Report of Public Speaking (PRPSA) developed by McCroskey (1970) consists of 34 questions on 5-point Likert-type scale that ranges from Strongly Disagree to Strongly Agree. It had exhibited reliability with Cronbach's alpha of .94 in three studies and a test-retest reliability of .84 over a 10-day period (McCroskey, 1970). The Personal Report of Public Speaking (PRPSA) was chosen for the present 
study for two reasons. First, unlike many other scales on speaking-related anxiety, it contains relevant questions to gauge oral presentation anxiety. Second, the PRPSA exhibited an acceptable level of reliability as it has been proven in the previous study (Pribyl, Keaten, and Sakamoto, 2001) showing extremely high levels of internal consistency. Therefore, PRPSA was considered the most appropriate instrument for the current study. In addition, PRPSA has been used in many recent studies for similar purposes (Chen, 2009; Chia, 2012; Swenson, 2011; Tse, 2011).

\subsubsection{Oral Communication Strategy Inventory}

Oral Communication Strategy Inventory was developed by Nakatani (2006). The questionnaire was given to undergraduate students in Japan, and all responded questions were analyzed and compared to the Strategy Inventory Language Learning (SILL). The finding revealed that students who reported frequent use of the SILL items also tended to report frequent use of OCSI items. Nakatani (2006) concluded that "the concurrent validity of the OCSI was generally recognized because the SILL has been regarded as an established scale for strategy use" (p.159). Therefore, the present study adopted the established questionnaire for its appropriateness and validity in measuring oral communication strategy use. Apart from its appropriateness, the questionnaire itself was divided into eight factors which present a clear distribution of each strategy (see Table 4).

Table 4 Subcategories of the Oral Communication Strategy (Nakatani, 2006)

\begin{tabular}{ll}
\hline Strategy Category & Item No. \\
\hline Social Affective Strategies & $23,25,26,27,28,29$ \\
Fluency-Oriented Strategies & $9,10,11,12,13,14$, \\
Negotiation for Meaning While Speaking & $19,20,21,22$ \\
Accuracy-Oriented Strategies & $7,8,17,18,30$ \\
Message Reduction and Alteration Strategies & $3,4,5$ \\
Nonverbal Strategies While Speaking & 15,16 \\
Message Abandonment Strategies & $6,24,31,32$ \\
Attempt to Think in English Strategies & 1,2 \\
\hline
\end{tabular}

\subsubsection{Semi-structured interviews}

A total of eight participants were chosen for the interview based on their anxiety levels and majors of study. Thus, participants in the interviews were categorized as high-anxiety and low-anxiety (4 in each group) and English major and non-English major (each anxiety level group includes 2 English majors and 2 non-English majors). The interview was to elicit participants' responses towards certain issues in presentation such as how they feel during academic presentations, difficulties they encounter in making presentations, opinions regarding their ability and other relevant issues.

\subsection{Data Collection Procedure}

The three questionnaires (background questionnaire, PRPSA, and OCSI) were administered on-line. An average of 10-15 minutes was needed for each participant 
to fill out these three instruments. Afterward, the participants were categorized into two levels - high-anxiety and low-anxiety-based on their PRPSA scores. For further analysis, eight students who indicated willingness to be interviewed were selected based on their anxiety level and majors. The interviews were conducted to gain more insightful answers to certain focused questions.

\section{FINDINGS}

\subsection{Questionnaire Responses}

\subsubsection{Factors contributing to participants' anxiety in oral presentation}

Altogether, the participants reported 10 sources of anxiety in total (see Table 5), in which content of presentation was the most frequently reported source of anxiety. Other than that, factors related to language proficiency and presentation skills (such as oral proficiency and delivery skill, and factors related to the audience (such as interaction and familiarity with the audience) were also considered anxietyprovoking. The fact that presentation content was reported as the most anxietyprovoking indicated that, to these graduate students, academic oral presentation did present a challenge dissimilar in nature from general oral presentations, for which oral proficiency is generally considered the most essential. For academic oral presentations to be successful, much more than a good command of oral English is needed.

Table 5 Sources of Anxiety Based on Checklist

\begin{tabular}{llll}
\hline Rank & Source of Anxiety & Frequency & Percentage (\%) \\
\hline 1 & Content of presentation & 48 & 78.6 \\
2 & Oral proficiency & 45 & 73.7 \\
3 & Delivery skill & 45 & 73.7 \\
4 & Professors' response & 35 & 57.3 \\
5 & Classmates' response & 27 & 44.2 \\
6 & Audience familiarity & 27 & 44.2 \\
7 & Accuracy of Pronunciation & 25 & 40.9 \\
8 & Handling software & 16 & 26.2 \\
\hline
\end{tabular}

Note: Two participants provided other options; they were time limit and language barrier (audiences' language ability).

\subsubsection{Participants' academic oral presentation anxiety levels}

Results of PRPSA questionnaire survey are presented in the following table.

Table 6 Percentage of responses to items in PRPSA $(N=61)$

\begin{tabular}{llllll}
\hline Item & Item statement & $M$ & $S D$ & $\begin{array}{l}\text { SD + D } \\
(\%)\end{array}$ & $\begin{array}{l}\text { A+ SA } \\
(\%)\end{array}$ \\
\hline 1 & $\begin{array}{l}\text { While preparing for the oral presentation, I } \\
\text { feel tense and nervous. }\end{array}$ & 3.28 & 1.03 & 18 & 45.9 \\
\hline $2 . \quad \begin{array}{l}\text { I feel tense when I saw the words "oral } \\
\text { presentation" on the course outline }\end{array}$ & 2.62 & 1.12 & 49.1 & 26.3 \\
\hline $3 . \quad \begin{array}{l}\text { My thoughts become confused and } \\
\text { jumbled when I give the oral presentation }\end{array}$ & 2.87 & 1.00 & 37.7 & 34.4 \\
\hline
\end{tabular}

Indonesian Journal of EFL and Linguistics, 3(2), 2018 


\begin{tabular}{|c|c|c|c|c|c|}
\hline 4. & $\begin{array}{l}\text { Right after giving the oral presentation I } \\
\text { feel that I have a pleasant experience. }\end{array}$ & 3.84 & 1.00 & 11.4 & 68.9 \\
\hline 5. & $\begin{array}{l}\text { I get anxious when I think about the oral } \\
\text { presentation coming up. }\end{array}$ & 3.20 & 1.15 & 26.2 & 44.3 \\
\hline 6. & $\begin{array}{l}\text { I have no fear of giving the oral } \\
\text { presentation. }\end{array}$ & 2.89 & 1.14 & 36.1 & 29.5 \\
\hline 7. & $\begin{array}{l}\text { Although I am nervous just before starting } \\
\text { the oral presentation, I soon settle down } \\
\text { after starting and feel calm and } \\
\text { comfortable. }\end{array}$ & 3.61 & 1.06 & 19.6 & 60.6 \\
\hline 8. & $\begin{array}{l}\text { I look forward to giving the oral } \\
\text { presentation. }\end{array}$ & 3.13 & 1.08 & 29.6 & 39.3 \\
\hline 9. & $\begin{array}{l}\text { When the professor announces there will } \\
\text { be oral presentation activities for the } \\
\text { course, I feel myself getting tense. }\end{array}$ & 2.70 & .95 & 42.6 & 21.3 \\
\hline 10. & $\begin{array}{l}\text { My hands tremble when I am giving the } \\
\text { oral presentation. }\end{array}$ & 2.61 & 1.02 & 45.9 & 18.1 \\
\hline 11. & $\begin{array}{l}\text { I feel relaxed while giving the oral } \\
\text { presentation. }\end{array}$ & 2.77 & 1.08 & 42.6 & 29.5 \\
\hline 12 & I enjoy preparing for the oral presentation. & 3.21 & 1.00 & 27.8 & 40.9 \\
\hline 13. & $\begin{array}{l}\text { I am in constant fear of forgetting what I } \\
\text { have prepared to say. }\end{array}$ & 2.92 & 1.13 & 36.1 & 36 \\
\hline 14. & $\begin{array}{l}\text { I will get anxious if someone asks me } \\
\text { something about my topic that I do not } \\
\text { know. }\end{array}$ & 3.43 & 1.16 & 23 & 59.1 \\
\hline 15. & $\begin{array}{l}\text { I face the prospect of giving the oral } \\
\text { presentation with confidence. }\end{array}$ & 3.51 & .92 & 14.7 & 55.8 \\
\hline 16. & $\begin{array}{l}\text { I feel that I am in complete possession of } \\
\text { myself while giving the oral presentation. }\end{array}$ & 3.21 & .89 & 21.3 & 37.7 \\
\hline 17. & $\begin{array}{l}\text { My mind is clear when giving the oral } \\
\text { presentation. }\end{array}$ & 3.23 & 1.00 & 26.2 & 39.4 \\
\hline 18. & I do not dread giving the oral presentation. & 3.08 & .98 & 27.9 & 39.4 \\
\hline 19. & $\begin{array}{l}\text { I perspire just before starting the oral } \\
\text { presentation. }\end{array}$ & 2.79 & 1.00 & 36.1 & 23 \\
\hline 20. & $\begin{array}{l}\text { My heart is beating very fast just as I start } \\
\text { the oral presentation. }\end{array}$ & 3.49 & 1.05 & 19.6 & 50.8 \\
\hline 21. & $\begin{array}{l}\text { I experience considerable anxiety while } \\
\text { sitting in the room just before my oral } \\
\text { presentation started. }\end{array}$ & 3.34 & 1.12 & 24.6 & 52.4 \\
\hline 22. & $\begin{array}{l}\text { Certain parts of my body felt very tense } \\
\text { and rigid while giving the oral } \\
\text { presentation. }\end{array}$ & 2.93 & 1.03 & 34.4 & 31.1 \\
\hline 23. & $\begin{array}{l}\text { Realizing that only a little time remains in } \\
\text { the oral presentation makes me very tense } \\
\text { and anxious. }\end{array}$ & 3.31 & 1.13 & 29.5 & 52.4 \\
\hline 24. & $\begin{array}{l}\text { While giving the oral presentation, I know } \\
\text { I can control my feelings of tension and } \\
\text { stress. }\end{array}$ & 3.54 & .90 & 11.5 & 59 \\
\hline 25. & I breathe faster just before starting the oral & 3.20 & 1.20 & 32.8 & 41 \\
\hline
\end{tabular}

Indonesian Journal of EFL and Linguistics, 3(2), 2018 


\begin{tabular}{|c|c|c|c|c|c|}
\hline & presentation. & & & & \\
\hline 26. & $\begin{array}{l}\text { I feel comfortable and relax in the hour or } \\
\text { so just before giving the oral presentation. }\end{array}$ & 2.92 & 1.13 & 36.1 & 31.2 \\
\hline 27. & $\begin{array}{l}\text { I will do poorer on the oral presentations } \\
\text { because I am anxious. }\end{array}$ & 3.15 & 1.15 & 31.2 & 42.6 \\
\hline 28. & $\begin{array}{l}\text { I feel anxious when the teacher announces } \\
\text { the dates for oral presentations. }\end{array}$ & 2.54 & 1.01 & 47.5 & 19.7 \\
\hline 29. & $\begin{array}{l}\text { When I make a mistake while giving the } \\
\text { oral presentation, I find it hard to } \\
\text { concentrate on the parts that follow. }\end{array}$ & 2.87 & 1.00 & 37.7 & 34.4 \\
\hline 30. & $\begin{array}{l}\text { During the oral presentation I experience a } \\
\text { feeling of helplessness building up inside } \\
\text { me. }\end{array}$ & 2.49 & .96 & 50.9 & 11.5 \\
\hline 31. & $\begin{array}{l}\text { I have trouble falling asleep the night } \\
\text { before oral presentation. }\end{array}$ & 2.08 & .98 & 72.1 & 9.8 \\
\hline 32. & $\begin{array}{l}\text { My heart is beating very fast while I am } \\
\text { presenting. }\end{array}$ & 3.00 & 1.06 & 36.1 & 36.1 \\
\hline 33. & $\begin{array}{l}\text { I feel anxious while waiting to give my } \\
\text { oral presentation. }\end{array}$ & 3.26 & 1.09 & 21.3 & 49.2 \\
\hline 34. & $\begin{array}{l}\text { While giving the oral presentation, I get so } \\
\text { nervous I forget facts I really know. }\end{array}$ & 2.84 & .93 & 34.4 & 24.6 \\
\hline & total & $\begin{array}{l}103.8 \\
6\end{array}$ & & & \\
\hline
\end{tabular}

According to the interpretation of PRPSA scores by Richmond and McCroskey (1995), participants of the present study experienced a moderate level of anxiety (A certain level of anxiety exists, but the respondents are still able to cope with it). Half of the participants perceived mistakes as common and did not think the mistakes interfered with their presentation, based on responses to item 29 (When I make a mistake while giving the oral presentation, I find it hard to concentrate on the parts that follow.). Regarding the tension and stress during presentation, the participants seemed rather capable of controlling such feelings, as 59\% of participants agreed or strongly agreed with item 24 (While giving oral presentation, I know I can control my feelings of tension and stress.).

In addition, when responding to item 27 (I will do poorer on the oral presentations because I am anxious.), $42.6 \%$ of participants agreed and strongly agreed with this statement. It seems that a self-perceived ability in oral presentation skill might play a role in leading an individual to be weather less or more anxious with respect to oral presentation. Half of the participants also stated that they feel worried when someone asks a question, as shown in item 14 (I will get anxious if someone asks me something about my topic that I do not know.).

A large proportion of participants $(55.8 \%)$ also believed that they have positive attitude toward presentation as a result of self-confidence. This answer refers to item 15 (I face the prospect of giving the oral presentation with confidence.). 
The finding of the current study is relevant to what's asserted by Crookall and Oxford (1991) in that severe language anxiety may adversely affect students' self esteem, self-confidence, and eventually hamper proficiency in language acquisition (as cited in $\mathrm{Wu}, 2010$ ). In this study a large number of participants responded negatively to questions that referred to their self-confidence in presentation skill (items 27 and 29), as shown in Table 6 above.

\subsubsection{Differences in strategy use between English majors and Non-English majors}

Independent sample t-test results indicated a significant difference existed between English majors and non-English majors in the use of Social Affective strategies.

Table 7 Comparison of OCSI scores between English majors and non-English majors

\begin{tabular}{|c|c|c|c|c|c|}
\hline Strategies & Group & $M$ & $S D$ & $t$ & $p$ \\
\hline \multirow{2}{*}{ Social affective } & English majors & 3.70 & 3.05 & \multirow[t]{2}{*}{-2.342} & \multirow[t]{2}{*}{$.02 *$} \\
\hline & Non-English majors & 3.99 & 2.56 & & \\
\hline \multirow{2}{*}{ Fluency oriented } & English majors & 3.51 & 3.22 & \multirow[t]{2}{*}{-.179} & \multirow[t]{2}{*}{.85} \\
\hline & Non-English majors & 3.54 & 3.52 & & \\
\hline \multirow{2}{*}{$\begin{array}{l}\text { Negotiation for } \\
\text { meaning while } \\
\text { speaking }\end{array}$} & English majors & 3.72 & 3.26 & \multirow[t]{2}{*}{-.456} & \multirow[t]{2}{*}{.65} \\
\hline & Non-English majors & 3.80 & 2.56 & & \\
\hline \multirow[b]{2}{*}{ Accuracy oriented } & Enolish maiors & 345 & 308 & \multirow[t]{2}{*}{-1.180} & \multirow[t]{2}{*}{.24} \\
\hline & Non-English majors & 3.63 & 2.33 & & \\
\hline \multirow{2}{*}{ Message reduction } & English majors & 3.82 & 1.66 & \multirow[t]{2}{*}{.123} & \multirow[t]{2}{*}{.90} \\
\hline & Non-English majors & 3.80 & 1.60 & & \\
\hline \multirow{2}{*}{$\begin{array}{l}\text { Nonverbal strategies } \\
\text { while speaking }\end{array}$} & English majors & 3.94 & 1.70 & \multirow[t]{2}{*}{-.854} & \multirow[t]{2}{*}{.39} \\
\hline & Non-English majors & 4.12 & 1.55 & & \\
\hline \multirow[b]{2}{*}{ Message abandonment } & English majors & 3 & 2.24 & \multirow[t]{2}{*}{650} & \multirow[t]{2}{*}{.51} \\
\hline & Non-English majors & 2.90 & 2.20 & & \\
\hline \multirow[b]{2}{*}{ Attempt to think } & English majors & 3.37 & 1.35 & \multirow[t]{2}{*}{.512} & \multirow[t]{2}{*}{.61} \\
\hline & Non-English majors & 3.27 & 1.67 & & \\
\hline \multirow{2}{*}{ Total score } & English majors & 3.53 & 10.9 & \multirow[t]{2}{*}{-1.07} & \multirow[t]{2}{*}{.28} \\
\hline & Non-English majors & 3.62 & 9.1 & & \\
\hline
\end{tabular}

$* P<.05$. 
Table 8 Comparison of Social Affective Strategy scores between English majors and non-English majors

\begin{tabular}{|c|c|c|c|c|c|}
\hline Social Affective strategies & Group & $M$ & $S D$ & $t$ & $p$ \\
\hline $\begin{array}{l}\text { I try to use fillers when I } \\
\text { cannot think of what to } \\
\text { say }\end{array}$ & $\begin{array}{l}\text { English majors } \\
\text { Non-English majors }\end{array}$ & $\begin{array}{l}3.54 \\
3.43\end{array}$ & $\begin{array}{l}1.06 \\
.72\end{array}$ & .477 & .63 \\
\hline $\begin{array}{l}\text { I try to give a good } \\
\text { impression to the listener }\end{array}$ & $\begin{array}{l}\text { English majors } \\
\text { Non-English majors }\end{array}$ & $\begin{array}{l}3.92 \\
4.00\end{array}$ & $\begin{array}{l}.88 \\
.78\end{array}$ & -.387 & .70 \\
\hline $\begin{array}{l}\text { I don't mind taking risks } \\
\text { even though I might make } \\
\text { mistakes }\end{array}$ & $\begin{array}{l}\text { English majors } \\
\text { Non-English majors }\end{array}$ & $\begin{array}{l}3.04 \\
3.78\end{array}$ & $\begin{array}{l}1.08 \\
.71\end{array}$ & -3.234 & $.002 *$ \\
\hline $\begin{array}{l}\text { I try to enjoy the } \\
\text { conversation }\end{array}$ & $\begin{array}{l}\text { English majors } \\
\text { Non-English majors }\end{array}$ & $\begin{array}{l}3.83 \\
4.27\end{array}$ & $\begin{array}{l}.86 \\
.56\end{array}$ & -2.393 & $.02^{*}$ \\
\hline $\begin{array}{l}\text { I try to relax when I feel } \\
\text { anxious }\end{array}$ & $\begin{array}{l}\text { English majors } \\
\text { Non-English majors }\end{array}$ & $\begin{array}{l}3.83 \\
4.08\end{array}$ & $\begin{array}{l}.96 \\
.64\end{array}$ & -1.209 & .23 \\
\hline $\begin{array}{l}\text { I actively encourage } \\
\text { myself to express what I } \\
\text { want to say }\end{array}$ & $\begin{array}{l}\text { English majors } \\
\text { Non-English majors }\end{array}$ & $\begin{array}{l}4.08 \\
4.38\end{array}$ & $\begin{array}{l}.83 \\
.54\end{array}$ & -1.679 & .09 \\
\hline
\end{tabular}

Use of Social Affective strategies indicates conscious efforts to control affective factors; moreover, use of such strategies allows learners to maintain a smooth flow of the conversation. T-test results on individual strategies in the category of Social Affective strategies revealed significant differences in risk-taking and trying to enjoy the conversation (See Table 8).

In Nakatani's (2006) study, the high oral proficiency group reported more use of three categories of strategies while speaking-social affective, fluency oriented, and negotiation for meaning. She stated that "students who recognized their use of those three types of strategies were judged as higher level of speakers of English (p.160)." However, the present study found that non-English major graduate students used more Social Affective strategies compared to English majors. It was possible that non-English majors were more aware of their difficulties in oral presentation in English and naturally made more frequent attempts to improve the flow of their presentation, while the English majors were more accustomed to making presentations in English and therefore had less need for such attempts. Another possible explanation is that most of the English-majors were Taiwanese graduate students while the non-English majors were international students. Such a difference in cultural background could entail a wide variety of factors (such as educational practices and valued learner characteristics) that might contribute to the difference in their reported use of Social Affective strategies. 


\subsubsection{Relationship between academic oral presentation anxiety and strategy employment}

To examine the relationship between academic oral presentation anxiety and strategy use, the Pearson product-moment correlation coefficients were computed. Results of the analysis are presented below.

Table 9 Correlation between Academic Oral Presentation Anxiety and Strategy Employment

\begin{tabular}{|c|c|c|c|c|c|c|c|c|c|}
\hline Dependent variables & PRPSA & SA & FO & NMS & $\mathrm{AO}$ & MR & NS & MA & $\begin{array}{l}\mathrm{A} \\
\mathrm{T}\end{array}$ \\
\hline PRPSA & -- & & & & & & & & \\
\hline Social Affective (SA) & $.327 *$ & -- & & & & & & & \\
\hline $\begin{array}{l}\text { Fluency-Oriented } \\
\text { (FO) }\end{array}$ & .047 & $.332 * *$ & -- & & & & & & \\
\hline $\begin{array}{l}\text { Negotiation for } \\
\text { Meaning While } \\
\text { Speaking (NMS) }\end{array}$ & $.340 * *$ & .249 & .189 & -- & & & & & \\
\hline $\begin{array}{l}\text { Accuracy-Oriented } \\
\text { (AO) }\end{array}$ & .091 & $.301 *$ & $.502 * *$ & .211 & -- & & & & \\
\hline $\begin{array}{l}\text { Message Reduction } \\
\text { and Alteration (MR) }\end{array}$ & -.241 & .172 & .071 & .119 & .30 & -- & & & \\
\hline $\begin{array}{l}\text { Nonverbal Strategies } \\
\text { while Speaking (NS) }\end{array}$ & $.345 * *$ & $.366^{* *}$ & .217 & $\begin{array}{l}.393 * \\
*\end{array}$ & $.268^{*}$ & -.010 & -- & & \\
\hline $\begin{array}{l}\text { Message } \\
\text { Abandonment ( MA) }\end{array}$ & $-.415 * *$ & .105 & -.039 & .022 & -.117 & $.312 *$ & -.233 & -- & \\
\hline $\begin{array}{l}\text { Attempt to Think in } \\
\text { English (AT) }\end{array}$ & $-.289 *$ & .122 & .102 & -.035 & -.033 & $\begin{array}{l}.331 * \\
*\end{array}$ & .062 & .164 & -- \\
\hline
\end{tabular}

$\mathrm{p}<.05$ (2-tailed). $* * \mathrm{p}<.01$ (2-tailed)

As seen in Table 9, significant positive correlations were found between total PRPSA scores and three subcategories on the strategy questionnaire-Social Affective, Negotiation for Meaning while Speaking, and Nonverbal strategies while speaking. In addition, significant negative correlations were found between PRPSA scores and two sbucategories of strategies-Message Abandonment and Attempt to Think in English. The strongest correlation existed between total anxiety scores and Message Abandonment strategies and Nonverbal strategies.

Comparing the results with previous studies (Nakatani, 2005, 2006) on differences in use of oral communication strategies by speakers of higher and lower proficiency, some inconsistency can be found. For example, in Nakatni's studies $(2005,2006)$, Message Abandonment strategies are usually considered ineffective communicative strategies and tend to be used more frequently by students of lower proficiency. As Nakatani claimed, "students who report using negative strategies could be regarded as ineffective strategy users in oral communication" (p.160). From such standpoint, results of the current study seem to contradict findings of previous studies. Since the current study assessed participants' anxiety level only and not proficiency level, and 
the participants were from multiple ethnic-cultural backgrounds, it is highly possible that the high and low-anxiety differentiation did not correspond to the participants' proficiency levels as well as it did in previous studies. The participants' different cultural and educational backgrounds are also very likely to introduce factors that influenced their self-report of anxiety, which might have resulted in the lack of correspondence with their proficiency levels.

As for Attempt to Think in English strategies, Nakatani's (2006) study indicates that low anxious students employed this strategy more frequently compared to Message Abandonment. Those using this strategy know how to convey the message properly because they map the sentence in their own native language before constructing it in English and also are able to convey the message to fit the situation. In this regard, the significant negative correlation found in the study is consistent with previous findings.

\subsubsection{Comparison of strategy use between high-anxiety and low-anxiety students}

Participants were divided into two groups-high anxiety and low anxiety-in accordance with their PRPSA scores. In Richmond and McCroskey's (1995) study, the mean score for PRPSA was used to determine participants' level of anxiety to obtain a more balanced number of participants in the two groups. Hence, those who scored at and above the mean (106 in the current study) were categorized as highanxiety and those scoring below 106 were categorized as low-anxiety. As a result, twenty-eight students belonged to the high-anxiety group, whereas thirty-three were regarded as low-anxiety.

Table 10 Comparison of OCSI Scores between High- and Low-Anxiety Groups

\begin{tabular}{|c|c|c|c|c|c|}
\hline Strategies & Group & $M$ & $S D$ & $t$ & $p$ \\
\hline \multirow{2}{*}{ Social affective } & High & 3.97 & 2.88 & \multirow{2}{*}{-1.467} & \multirow{2}{*}{.14} \\
\hline & Low & 3.79 & 2.79 & & \\
\hline \multirow{2}{*}{ Fluency oriented } & High & 3.48 & 3.70 & \multirow{2}{*}{.532} & \multirow{2}{*}{.59} \\
\hline & Low & 3.56 & 3.13 & & \\
\hline \multirow{2}{*}{$\begin{array}{l}\text { Negotiation for meaning while } \\
\text { speaking }\end{array}$} & High & 3.89 & 2.75 & \multirow{2}{*}{-1.247} & \multirow{2}{*}{.21} \\
\hline & Low & 3.66 & 2.88 & & \\
\hline \multirow{2}{*}{ Accuracy oriented } & High & 3.52 & 3.03 & \multirow{2}{*}{.474} & \multirow{2}{*}{.63} \\
\hline & Low & 3.59 & 2.36 & & \\
\hline \multirow{2}{*}{ Message reduction } & High & 3.69 & 1.74 & \multirow{2}{*}{1.599} & \multirow{2}{*}{.11} \\
\hline & Low & 3.91 & 1.46 & & \\
\hline \multirow{2}{*}{$\begin{array}{l}\text { Nonverbal strategies } \\
\text { speaking }\end{array}$} & High & 4.19 & 1.52 & \multirow{2}{*}{-1.325} & \multirow{2}{*}{.19} \\
\hline & Low & 3.92 & 1.66 & & \\
\hline \multirow{2}{*}{ Message abandonment } & High & 2.69 & 2.47 & \multirow{2}{*}{3.371} & \multirow{2}{*}{$.002 *$} \\
\hline & Low & 3.15 & 1.56 & & \\
\hline \multirow{2}{*}{ Attempt to think in English } & High & 3.14 & 1.56 & \multirow{2}{*}{1.584} & \multirow{2}{*}{.11} \\
\hline & Low & 3.45 & 1.50 & & \\
\hline \multirow{2}{*}{ Overall score } & High & 3.56 & 9.9 & \multirow{2}{*}{.535} & \multirow{2}{*}{.594} \\
\hline & Low & 3.59 & 10.0 & & \\
\hline
\end{tabular}

Indonesian Journal of EFL and Linguistics, 3(2), 2018 
Overall, high-anxiety participants did not apply strategies more frequently. A significant difference was found in their use of Message Abandonment strategies only-high-anxiety participants gave up less frequently on their attempts to make their presentation clear. As explained earlier, the anxiety level measured in the study might not correspond neatly to the proficiency level of the participants, and the participants' socio-cultural background might also affect how they perceive the task of giving oral presentations. For example, students from certain countries may not feel so comfortable with giving oral presentations, but that does not necessarily mean that their oral proficiency is lower.

\subsection{Interview Responses}

Four students from each of the anxiety level group were invited (two majors and two non-majors) to share their opinions regarding oral academic presentation. Based on the interviewees' responses, the results are presented below concerning three issues: factors contributing to speaking anxiety, comments during presentation, and use of nonverbal cues.

Table 11 Participants' Interview Group Distribution

\begin{tabular}{llll}
\hline No & Pseudo name & Major & Anxiety level \\
\hline 1 & A and B & English & High \\
2 & C and D & English & Low \\
3 & E and F & Non-English & High \\
4 & G and H & Non-English & Low \\
\hline
\end{tabular}

\subsubsection{Factors contributing to speaking anxiety}

Both major and non-majors mentioned language barrier as an important factor causing anxiety while making oral presentations. The participants reported that while using a second language to make presentations, they would place more emphasis on accuracy of language use, which often means writing down every word they were going to say in front of the audience beforehand. The participants recognized that using a foreign language prevented them from making a more powerful presentation. This finding is relevant to Elliot and Chong (2004) in that international students for whom English is not the first language placed a greater emphasis on personal attributes, namely language and communication skills.

In addition, one participant mentioned cultural difference as a barrier. He commented that when using his native language, there were more resources for him to impress the audience like using humor, but in a foreign classroom (in this case Taiwan), he wasn't sure if the local or other foreign students could understand his humor. Thus, he often chose the "safe way" to make his presentation as straight forward as possible.

Lack of experience was also a contributing factor to anxiety. As some participants commented, they were not used to making oral presentations in class. In their past experience, they were mostly required to just pay attention to lectures in class; therefore, making oral presentations was a rather unfamiliar activity to them. The 
lack of practice often led to higher anxiety. As mentioned earlier, cultural and educational background matter a lot in participants' reported level of anxiety. Though higher language proficiency might lessen participant's anxiety, lack of practice would still render oral presentation a highly anxiety-provoking activity.

\subsubsection{Comments/questions for presentation}

Another issue reported to raise anxiety is comments and questions, either from professors or peers, which is discussed in two aspects - mode and timing. Most interviewees regarded comments and questions as one main factor causing anxiety, but at the same time recognized the benefits of receiving feedback for future improvement. However, interviewees differed with regard to their preference for spoken or written comments. The non-English majors tended to prefer spoken comments because when comments were delivered orally, at least they could see the facial expressions and ask for further explanations to benefit more from the comments. The English majors, on the other hand, preferred written comments because they were mainly concerned over not being able to address the spoken comment immediately, especially for comments that ask for further explanations on the content of presentation. The difference might have been caused by the nature of presentation content; most presentations for English majors dealt with information or opinions in words, while non-English majors often presented information in numbers or equations, which might be more readily explainable, especially for engineering and industrial management majors.

As for the time for receiving comments, two interviewees expressed their dislike of being interrupted by comments or questions from professors or peers. They considered comments during presentation as rude and could add more anxiety to the task itself. They preferred receiving comments and questions after the presentation when they could fully concentrate on responding to the comments. As reported in Radzuan and Kaur (2011), comments or criticisms during presentation add to the challenge of the already anxiety-provoking task of presentation delivery.

In addition, local students in the audience were also reported to be reluctant to ask questions, as reported by most participants in the interviews. Similar finding was also reported by Kim (2007) who indicated that East Asian graduate students remained silent in classroom as a way to actively participate in the classroom and considered listening to be the most important skill for academic success.

\subsubsection{Nonverbal cues}

In terms of nonverbal cues like eye contact and hand gestures, all interviewees recognized the effectiveness of using nonverbal cues to make better oral presentations. However, neither low nor high-anxiety interviewees were quite able to use nonverbal cues comfortably, especially eye contact, to enhance their performance. The low-anxiety interviewees reported using some gestures to shift the audience's attention (so the audience wouldn't look directly at their faces while they presented) but still found it hard to maintain eye contact. So in the end they reported looking at the audience not in the eye but on the hair. High-anxiety interviewees mentioned using gestures to help themselves relax but reported feeling the need to 
look at their power point slides instead of the audience so that they wouldn't forget the content of presentation. Overall, the interviewees, regardless of their major and anxiety level, were not quite proficient in the use of nonverbal cues as a strategy to improve their oral presentation performance; instead, they tended to use it to distract audience's attention or hide their nervousness.

\section{DISCUSSION AND IMPLICATIONS}

Results of the current study highlighted some issues worth considering in the discussion of public speaking anxiety.

\subsection{Conspicuousness}

Though a common classroom task for graduate students, making academic oral presentations is still highly anxiety-provoking because it focuses everyone's attention on the presenter. As described by Dalkilic (2001), conspicuousness is one of the leading causes of classroom speaking anxiety. When a learner feels everyone in the classroom, including the professor, is focused on what he or she says and how he or she says it, the effects of all the other contributing factors to anxiety, such as lack of confidence and knowledge (Dalkilic, 2001), deficiency in speaking skills or linguistic proficiency in general (Philips, 1999; Horwitz, Horwitz, \& Cope, 1986), and fear of negative evaluation (Mak, 2011) become stronger, leading to increased anxiety which usually impairs performance. As explained by Hadziosmanovic (2012), speaking a foreign language itself may not be a cause of anxiety, but speaking in front of the whole class is. In the case of making academic oral presentations, it is particularly so because it involves not just speaking a foreign language, but also explaining professional content in a well-organized academic style in front of the whole class, and possibly even receiving and answering questions from the audience. For oral presentations to proceed smoothly, students need to be made aware of or even directly instructed on practical strategies to lessen the detrimental impact of public speaking anxiety due to conspicuousness.

\subsection{Classroom Dynamic}

As seen from the participants' responses, the audience plays an important role in how they view the task of making oral presentations. Though different preferences were reported on the receiving mode of feedback, the participants indicated great concern over not being able to comprehend or respond well to questions or comments from the professors or classmates. Previous studies have pointed out that speaker's relationship with classmates and class atmosphere influence how they perceive the speaking task and their anxiety level when engaging in speaking activities (Tamina, 2015; Hadziosmanovic, 2012). Slater, Pertaub, and Barker (2002) stated that though sources of public speaking anxiety may vary between one and another, negative audience did play a role in provoking anxiety. Those who speak to an audience that reacts negatively by not paying attention or showing a negative attitude will experience greater anxiety. On the other hand, those who speak to a static or positive audience will have lower anxiety. Therefore, to help reduce students' anxiety in making oral presentations, instructors may try to create a 
more supportive class atmosphere and provide more opportunities for more positive and constructive peer interactions (Matsuda \& Gobel, 2004).

\subsection{Socio-Cultural Background}

As reported by some participants, they were not quite accustomed to making oral presentations in class due to their previous educational experiences. Since most participants in the present study were from Asian countries, they reported being more with familiar with listening to lectures in class and feeling less comfortable with making oral presentations in front of the class. In most Asian culture, under the influence of Confucianism, paying attention to the teacher is often considered a way to show respect while voicing opinions is rarely emphasized ( $\mathrm{Hu}, 2002$; Lim, 2003; Rao, 2001). Hence, English learners from Confucian heritage cultures seemed to be more anxious than other ethnic groups when it comes to interacting with native English speakers (Woodrow, 2006). In addition, memorizing information correctly, instead of expressing opinions or evaluating what's learned, is often strongly emphasized in tests, which may lead to participants' excessive concern over making mistakes (either linguistically or content-wise) in front of everyone during presentation. Moreover, as mentioned by one interviewee, differences in cultural background also limited the ability to make effective delivery because the audience might not have understanding of the native culture or are used to different norms of delivery. Hence, for classes with students from different cultural backgrounds, in addition to focusing on language ability and strategies to cope with stage fright, it might help to some extent if sufficient understanding of general and educational norms of both students' native and local culture is emphasized in class.

\subsection{Training in Oral Academic Presentation}

Based on findings of the present study, making oral academic presentations indeed presents a task different from regular classroom speaking activities; therefore, participants reported experiencing anxiety stemming from not just language proficiency, but also familiarity with content and presentation skills, and audiencerelated factors. The findings suggest a real need to formally train graduate students on presentation skills, including useful strategies to use in presentation, delivery skills, norms of academic presentations, and effective use of non-verbal cues. Graduate-level courses on academic presentations should focus on those aspects mentioned above as well as the content of presentation. Previous studies have identified effective strategies used by more proficient learners, and experiments have been conducted to confirm the benefit of explicit instruction on reducing students' public speaking anxiety (Chou, 2011; Colbeck, 2011; Huang, 2010; Knight, Johnson, \& Stewart, 2016; Nakatani, 2005; Pribyl, Keaten, and Sakamoto; 2001; Wong \& Nunan, 2011). To address the need of graduate students in making successful academic oral presentations, similar instructional programs can be designed targeting the skills most lacking for graduate students.

\section{CONCLUSION}

The present study investigates graduate students' (including Taiwanese and foreign graduate students, English and Non-English majors) anxiety level and use of 
strategies in making academic oral presentations. The findings indicate that overall, the participants experienced a moderate level of anxiety, which comes mainly from content of presentation, oral proficiency, and lack of delivery skills. Comparison of participants from different majors showed that non-majors used more Social Affective strategies, particularly taking risks in communication and trying to enjoy the conversation, indicating a more active stance in oral communication. In addition, high-anxiety participants, contrary to previous research findings, were found to use less Message Abandonment strategies. Cultural factors might have played a role in how the results differed from previous studies.

Based on interview results, it was found that cultural backgrounds play a significant role in participants' anxiety level. For EFL learners, especially participants of the present study, making academic oral presentations in a foreign language could be a rather unfamiliar activity in their previous educational experience, and using a foreign language might limit their resources to achieve better presentation effects. Also, the interview responses indicate a need for presentation skills training. Although most interviewees understood the importance of using nonverbal cues in enhancing presentation effect, they reported not feeling comfortable using them and ended up using nonverbal cues to cover their nervousness. Therefore, for EFL graduate students, there is a need to explicitly teach them effective strategies in giving academic oral presentations in English. More importantly, training in applying the strategies is also necessary so that good presentation skills can be translated from mere knowledge into practice.

\subsection{Future Studies}

In the present study, although comparisons were made between English and nonEnglish majors and high and low-anxiety learners, variety in ethnic and cultural backgrounds of the participants introduced some confounding variables which compromised the interpretability of results. Therefore, future studies can either control the ethnic or educational background of the participants and interpret the results as applicable to students of a certain background, or include ethnic or cultural background as a variable and compare the data to find out differences between students from different ethnic or cultural backgrounds. Furthermore, the anxiety level reported by the participants in the present study might not correspond well to their proficiency level, resulting in inconsistency with findings of previous studies. Future studies may include measures of oral proficiency levels to further explore the relationship between anxiety, proficiency level, and strategy employment.

\section{REFERENCES}

Amhed, N., Pathan, Z. H., \& Khan, F. S. (2017). Exploring the causes of English language speaking anxiety among postgraduate students of university of Balochistan, Pakistan. International Journal of English Linguisitcs, 7(2), 99105.

Amiri, F, \& Puth, M. (2018). Oral communication apprehension among international doctoral students. English Language Teaching, 11(2), 164-171. 
Amiryousefi, M. \& Tavakoli, M. (2011). The relationship between test anxiety, motivation and MI and the TOEFL IBT Reading, Listening and Writing Score. Procedia Social and Behavioral Sciences, 15, 210-214.

Busá. M. G. (2010). Sounding natural: improving oral presentations skills. Language Value, 2(1), 51-67.

Chen. L. (2009). A study of EFL graduate students' oral presentation anxiety. Unpublished master's thesis. National Chung Cheng University, Chiayi. Taiwan.

Chou. M.. H. (2011). The influence of learner strategies on oral presentation: A comparison between group and individual performance. English for Specific Purposes, 30. 272-285.

Colbeck, J. J. (2011). The impact of a fundamentals of speech course on public speaking anxiety. The Journal of Undergraduate Research, 9, 145-160.

Dalkilic, N. (2001). The role of foreign language classroom anxiety in English speaking courses. Cukuroval Universitesi Sosyal Bilimler Enstitusu Dergisi,8(8). $\quad$ Retrieved August 11, 2017 from http://www.academia.edu/487254/The_Role_Of_Foreign_Language_Classroo m_Anxiety_in_English_Speaking_Courses

Elliot, J. and Chong, J.L.Y. (2005). Presentation Anxiety: A Challenge for Some Students and a Pit of Despair for Others. Retrieved March 23, 2015 from http://www.isana.org.au/files/20051017165939_PresentationAnxiety.pdf

Elliott, J. \& Chong, J.L.Y. (2004). Presentation anxiety: A challenge for some students and a pit of despair for others. Challenging education: Socio-cultural, economic and academic outcomes: Proceedings of the 15th ISANA International Conference, 2004, 30 November-3 December, 2004, Grand Hayatt, Melbourne, Victoria.

Hadziosmanovic, L. (2012). Students' Perspective on Speaking Anxiety and Dynamics in the ESL Classroom. Retrieved May 15, 2017 from https://muep.mau.se/bitstream/handle/2043/13641/Speaking\%20Anxiety\%20a nd\%20Classroom\%20Dynamics.pdf? sequence $=2$

Hashemi, M. (2011). Language stress and anxiety among the English language learners. Procedia Social and Behavioral Sciences, 30, 1811-1816.

Hewitt, E. \& Stephenson, J. (2012). Foreign language anxiety and oral exam performance: a replication of phillips's MLS study. The Modern Language Journal, 99, 170-189.

Horwitz, E., Horwitz, M., \& Cope, J. (1986). Foreign language classroom anxiety. The Modern Language Journal, 70, 125-132.

Hsu, T. C. (2012). A study on the EFL students' speech related anxiety in Taiwan. International Journal of Research Studies in Language Learning, 1(2), 3-18.

$\mathrm{Hu}$, G. (2002). Potential cultural resistance to pedagogical imports: The cases of communicative language teaching in China. Language, Culture and Curriculum. Retrieved March 23, 2017 from http://www.multilingualmatters.net/lcc/015/0993/lcc0150993.pdf 
Huang, L. (2010). Do different modalities of reflection matter? An exploration of adult second-language learners' reported strategy use and oral language production. System, 38, 245-261.

Kim, J. (2007). Active verbal participation in U.S Classrooms: Perception of East ASIAN international graduate students. (Unpublished Doctoral Dissertation). Ohio State University, USA.

King, J. (2002). Preparing EFL learners for oral presentations. Dong Hwa Journal of Humanistic Studies, 4, 401-418.

Khatt et al. (2011). An investigation into causes of English language learning anxiety in students at AWKUM. Procedia Social and Behavioral Science, 15, 1600-1604.

Knight, M. L., Johnson, K. G., \& Stewart, F. (2016). Reducing student apprehension of public speaking: Evaluating effectiveness of group tutoring practices. TLAR, 21(1), 21-52.

Kunt, N. \& Tum, D. (2010). Non-native student teachers' feelings of foreign language anxiety. Procedia Social and Behavioral Sciences, 2, 4672-4676.

Lim, H. Y. (2003). Successful classroom discussions with adult Korean ESL/FL learners. The Internet TESL Journal, 11(5). Retrieved February 17, 2015 from http://iteslj.org/Techniques/Lim-AdultKoreans.html

Matsuda, S. \& Gobel, P. (2004). Anxiety and predictors of performance in the foreign language classroom. System, 32 (1), 21-36.

Mak, B. (2011). An exploration of speaking-in-class anxiety with Chinese ESL learners. System, 39, 202-214.

Mazdayana, G. (2012). Objective assessment of Oral presentation and EFL learners' speaking development. Sheikhbahaee EFL Journal, 1(1), 23-36.

McCroskey, J. C. (1970). Special reports: Measures of communication-bound anxiety. Speech Monograph, 37, 269-277.

Nakatani, Y. (2005). The effects of awareness-raising training on oral communication strategy use. The Modern Language Journal, 89(1), 76-91.

Nakatani, Y. (2006). Developing an oral communication strategy inventory. The Modern Language Journal, 90, 151-168.

Neff, P. E. (2007). The roles of anxiety and motivation in language learner task performance. Doshisha Studies in Language and Culture, 10(1), 23 - 42.

Phillips, E. M. (1999). Decreasing language anxiety: Practical techniques for oral activities. In D. J.Young (Ed.) Affect in Foreign Language and Second Language Learning: A Practical Guide to Creating a Low-Anxiety Classroom Atmosphere, 124-143.

Pribyl, C. B., Keaten, J., Sakamoto, M. (2001). The effectiveness of a skills-based program in reducing public speaking anxiety. Japanese Psychological Research, 43(3), 148-155.

Radzuan and Kaur. (2011). Technical oral presentation in English: qualitative analysis of Malaysian engineering undergraduates' source of anxiety. Procedia Social Behavioral Sciences, 29, 1436-1445.

Richmond, V. P., \& Mccroskey, J. C. (1995). Communication: Apprehension, Avoidance, and Effectiveness, $4^{\text {th }}$ edition. Scottsdale, AZ: Gorsuch Scarisbrick. 
Rao, Z. H. (2001). Matching teaching styles with learning styles in East Asian contexts. The Internet TESL Journal, 7(7). http://iteslj.org/Techniques/Zhenhui-TeachingStyles.html

Samimy, K. K., \& Tabuse, M. (1992). Affective variables and a less commonly taught language: A study in beginning Japanese classes. Language Learning, 42, 377-398.

Slater, M., Pertaub, D. P., Barker, C. (2002). An experiment on public speaking anxiety in response to three different types of virtual audience. Presence, 11, 68-78.

Slater, M., Pertaub, D. P., Barker, C. Clark, D. M. (2006). An experimental study on fear of public speaking using virtual environment. Cyiber Psychology \& Behavior, 9(5), 627-633.

Swenson. A. (2011). You make my hearth beast faster: a quantitative study of the relationship between instructor immediacy, classroom community and public speaking anxiety. UW-L journal of Undergraduate Research XIV, 1-12.

Tamina, S. (2015). Causes of English speaking anxiety among Taiwanese university students. Proceedings of INTCESS15-2 ${ }^{\text {nd }}$ International Conference on Education and Social Sciences, pp. 1305-1309.

Tse. T. (2011). To be anxious or not to be anxious - that's the question in public speaking. $4^{\text {th }}$ Biennial International Conference on the Teaching and Learning of English in Asia.

Visatari, P., Wahab, A. N. M., Othman, A., Awang, G., M. (2010). A research for identifying study anxiety sources among university students. International Education Studies, 3, (2), 189-196.

Wong L. L. C., Nunan. D. (2011). The learning styles and strategies of effective language learners. System, 39,144-163.

Woodrow. L. (2006). Anxiety and speaking English as a second language. RELC, 37(3), 308-328.

Wu, K.H. (2010). The relationship between language learners' anxiety and learning strategy in the CLT classroom. International Education Studies, 3(1). 174-191.

Young, D. J. (1990). An investigation of students' perspectives on anxiety and speaking. Foreign Language Annals, 23(6), 539-553.

Yusoff. M. (2008). Communication in oral presentation: A Malaysian Experience Paper presented at the IEEF symposium. Retrieved July 02, 2012, from IEEE Xplore.

Yusoff. M. (2010). Analyzing communication competence in oral presentations: engineering students' experiences. Journal of Human Capital Development, 3(1), 99-117. 